\title{
Occurrence of Stercorarius pomarinus (Temminck, 1815, Charadriiformes: Stercorariidae) in the Cananéia estuary, southern coast of São Paulo State
}

\author{
Edison Barbieri ${ }^{1,3}$ \& Douglas Bete ${ }^{2}$ \\ ${ }^{1}$ Instituto de Pesca, Agência Paulista de Tecnologia dos Agronegócios Paulista - APTA, \\ Secretaria de Agricultura e Abastecimento do Estado de São Paulo, Av. Professor Besnard, s/n, \\ Morro do São João, CP 61, CEP 11990-000, Cananéia, SP, Brasil \\ ${ }^{2}$ Escola Estadual Francisco Camargo Cesar, CEP 18071-286, Sorocaba, SP, Brasil \\ ${ }^{3}$ Corresponding author: Edison Barbieri, e-mail: edisonbarbieri@yahoo.com.br
}

BARBIERI, E. \& BETE, D. Occurrence of Stercorarius pomarinus (Temminck, 1815, Charadriiformes: Stercorariidae) in Cananéia estuary, Southern Coast of São Paulo State, Brazil. Biota Neotrop. 13(1): http:// www.biotaneotropica.org.br/v13n1/en/abstract?article+bn00613012013

Abstract: Many Neartic seabirds migrate to South America for the non-breeding season, using several key stopover and wintering sites along the Atlantic coast. The Stercorarius pomarinus is a widely distributed seabird found in every Ocean. It is a migratory bird from northern North America that flies southwards. However, there is little information about the occurrence of Stercorarius pomarinus along the São Paulo State coast. Former publications concerning the birds of Iguape- Cananéia- Ilha Comprida estuary have made no mention of the presence of this bird in the region. Thus it is important that forthcoming appearances be recorded. Throughout the bird-sample selection stage, undertaken since 1998 in the Cananéia estuary (2502’ 44.71” S and 47 55’ 14.58” W) - 272 km from the city of São Paulo -, the bird was seen for the first time, resting in the Cananéia estuary, in January (2012). This note reports the occurrence of Stercorarius pomarinus in the Cananéia estuary, on the southern coast of São Paulo State, Brazil.

Keywords: seabird, migration, Cananéia, São Paulo, Stercorarius pomarinus.

BARBIERI, E. \& BETE, D. Ocorrência de Stercorarius pomarinus (Temminck, 1815, Charadriiformes: Stercorariidae) no estuario de Cananéia, Litoral sul do Estado de São Paulo. Biota Neotrop. 13(1): http:// www.biotaneotropica.org.br/v13n1/pt/abstract?article+bn00613012013

Resumo: Muitas aves marinhas Neárticas migram para as regiões de invernadas localizadas na América do Sul, utilizando várias rotas e pontos de paradas ao longo da costa do Oceano Atlântico. O mandrião-pomarino é uma ave marinha que migra após a reprodução e pode ser encontrada no Atlântico Sul, entretanto, há poucas informações sobre a ocorrência desta ave o longo da Costa do Estado de São Paulo. Publicações anteriores a respeito da avifauna do estuário de Iguape, Cananéia, Ilha Comprida não fazem menção à presença da Stercorarius pomarinus na área, o que justifica a importância de relatar novos registros desta ocorrência. O registro aqui relatado foi obtido a partir de atividade de monitoramento conduzido desde 1998, no estuário de Cananéia (2502' 44.71" S e $47^{\circ} 55^{\prime} 14.58^{\prime}$ W), onde foi realizada a avistagem de dois espécimes de Stercorarius pomarinus em apenas uma oportunidade, no mês de janeiro de 2012, pousadas num banco de areia no meio do estuário.

Palavras-chave: ave marinha, ocorrência, Cananéia, São Paulo, Stercorarius pomarinus. 


\section{Introduction}

Stercorarius pomarinus is similar to the other Stercorariidae, which frequently chase other sea birds to steal their food from them, thus being kleptoparasites. However, this bird also feeds on rodents, small birds such as the terns and even sea-gulls (Dunning 1992).

This seabird reproduces in the Arctic region (Canada, Greenland and northern Siberia). It makes its nest in the Arctic tundra, laying 2 or 3 eggs in depressions in the ground, lined with grass (Olsen \& Larsson 1997).

S. pomarinus is a trans-equatorial migrant which winters in the Atlantic Ocean on the African coast (South Africa, Namibia and Angola). In the western South Atlantic it is considered rare or sporadic (Olsen \& Larson 1997). In Brazil it occurs mainly during its migratory flights (Sick 2001).

In Brazil the first report of S. pomarinus was made, on the estuary of the Tapajós river, by Escalante (1972). Olmos (1997), observing the birds associated with fishing boats on the continental platform of the Brazilian south-east. Olmos (2000) suggest that this bird is more common than perceived at first sight in oceanic waters

\section{Materials and Methods}

The record of $S$. pomarinus was retrieved one of the census of project "estuarine bird", which is developed in the estuary of Cananéia, São Paulo (Figure 1). Data collection for this project consists in conducting censuses in fixed points within the sandy bank near aquatic environments (Figure 1), with fortnightly frequency, since 2010.

\section{Result and Discussion}

The observation reported here was made on 14 January 2012 during active searches performed from morning to approximately 10:00 AM.

Olmos (1997, 2000) registered Stercorarius pomarinus between 23 and 27 November, 1994 and between 24 and 30 March, 1995, on the coast of São Paulo. These present authors observed two specimens of $S$. pomarinus on a sandbank $\left(25^{\circ} 02^{\prime} 44.71^{\prime \prime} \mathrm{S}\right.$ and $47^{\circ} 55^{\prime} 14.58^{\prime \prime}$ W) in the Cananéia estuary, São Paulo, identified as S. pomarinus. Two photographs of these specimens (Figures 2 and 3) showed S. pomarinus, with a dark double-colored beak, shanks of a lighter color than the feet, and greatly elongated, pointed central tail feathers, and that seemed to be quite tame.

The species occurs with a variety of plumage that may vary from a completely dark tone, to light-colored individuals with white necks, with all the possible intermediate stages of plumage. In Figures 2 and 3 it is possible to observe the clearly two-colored beak and in Figure 3 the wide central tail feathers with the rounded extremities, typical of S. pomarinus. This is the first registered report of the species in the Cananéia estuary, and the second for the State of São Paulo (Olmos 2000). It is important to emphasize that in Numao \& Barbieri's study (2011) of the birds of the Cananéia estuary, as in that of Barbieri \& Tavares (2008) on the birds of Ilha Comprida, there is no record of any specimen of this species. In accordance with Olmos's (2000) records, the species seems to be more common on the Brazilian

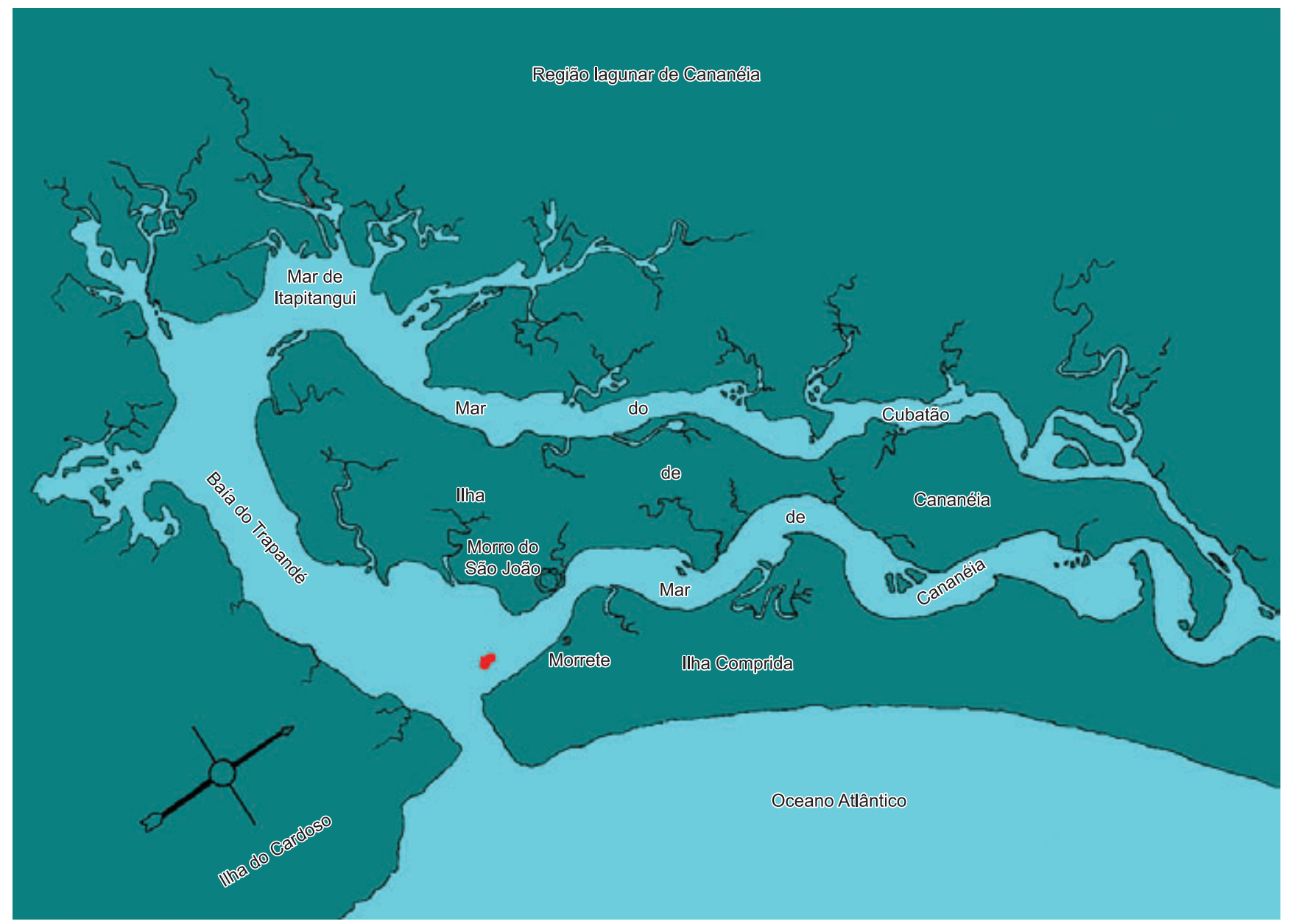

Figure 1. In red area in which Stercorarius pomarinus was observed in sandbank in Cananéia estuary, São Paulo, State. 


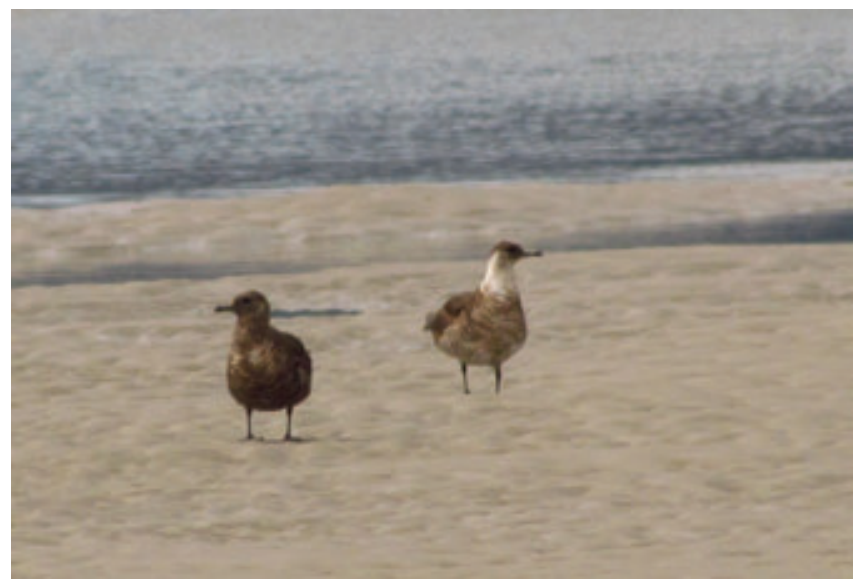

Figure 2. Two Stercorarius pomarinus photographed at $25^{\circ} 02^{\prime} 44.71^{\prime \prime} \mathrm{S}$ and $47^{\circ} 55^{\prime} 14.58^{\prime \prime} \mathrm{W}$ in January 2012. (Photo Douglas Bete).

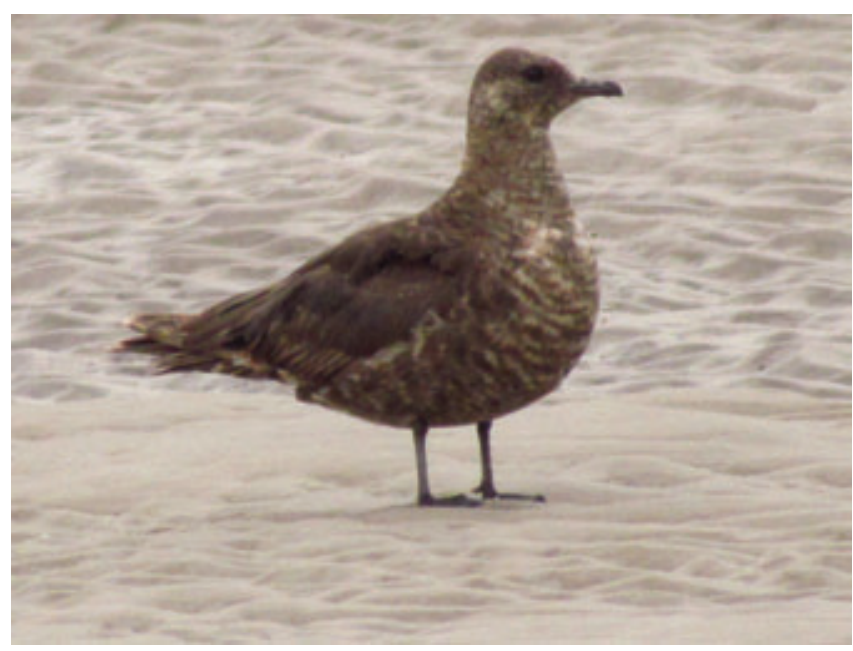

Figure 3. Stercorarius pomarinus photographed at $25^{\circ} 02^{\prime} 44.71^{\prime \prime} \mathrm{S}$ and $47^{\circ}$ $55^{\prime} 14.58$ " W in January 2012. (Photo Douglas Bete). southeast/south coast than was at first perceived. Pelagic seabirds are very common in Brazilian waters but there is very little study about this bird group. They are frequently represented by few reports, due mainly to the difficulties encountered in studying them. The lack of research and of specific funding for projects on sea-birds have resulted in a paucity of studies undertaken in the habitats of these species, giving the possibly erroneous impression of their rarity.

The region of the Cananéia-Iguape-Ilha Comprida estuary is important in terms of primary production. The productivity of this ecotope accounts for the large numbers of terns which feed here throughout the year (Barbieri \& Pinna 2007). The presence of the terns may have attracted the $S$. pomarinus, as this latter bird is a kleptoparasite (Dunning 1992). This latter fact was confirmed by two attacks of the $S$. pomarinus on the Thalasseus acuflavidus, observed on this same occasion.

\section{References}

BARBIERI, E. \& TAVARES E.P. 2008. The birds at Ilha Comprida beach (São Paulo state, Brazil): a multivariate approach. Biota Neotrop. 8(3): http:// www.biotaneotropica.org.br/v8n3/en/abstract?article+bn00408032008.

BARBIERI, E. \& PINNA, F.V. 2007. Variação temporal do trinta-réis-debico-amarelo (Thalasseus sandvicensis eurygnatha) durante o ano de 2005 no estuário de Cananéia-Iguape-Ilha Comprida. Ornitologia Neotropical. 18:563-572.

DUNNING JUNIOR, J.B. 1992. CRC Handbook of Avian Body Masses. CRC Press.

ESCALANTE, R. 1972. First Pomarine Jaeger specimen from Brazil. Auk 89(3):663-665.

NUMAO, F. \& BARBIERI, E. 2011. Variação sazonal de aves marinhas no baixio do Arrozal, município de Cananeia-SP. Mundo Saúde 35(1):71-83.

OLMOS, F. 2000. Revisão dos registros de Stercorarius pomarinus no Brasil, com notas sobre registros de $S$. longicaudus e $S$. parasiticus (Charadriiformes: Stercorariidae). Nattereria (1):29-33

OLMOS, F. 1997. Seabird flocks attending bottom longline fishing off southeastern Brazil. Ibis 139(4):685-691. http://dx.doi.org/10.1111/ j.1474-919X.1997.tb04692.x

OLSEN, K.M. \& LARSSON, H. 1997. Skuas and jaegers: a guide to the skuas and jaegers of the world. Yale University Press, New Haven.

SICK, H. 2001. Ornitologia brasileira. 3. ed. Editora Nova Fronteira, Rio de Janeiro. 